Balkan Araştırma Enstitüsü Dergisi / Journal of Balkan Research Institute Cilt/Volume 8, Sayı/Number 1, Temmuz/July 2019, ss. 61-83.

Geliş Tarihi-Received Date: 15.02.2019

Kabul Tarihi-Accepted Date: 15.04.2019

DOI: 10.30903/Balkan.584080

ARAŞTIRMA MAKALESİ - RESEARCH ARTICLE

\title{
KIBRIS VE GAGAVUZ \\ TÜRK HALK MASALLARINDAKİ KADIN KAHRAMANLAR VE SOSYO-KÜLTÜREL ROLLERİ
}

\section{Burak GÖKBULUT*-Mustafa YENİASIR***}

\begin{abstract}
$\ddot{O Z Z}$
Kıbrıs Türklerinin halk masalları ağız özellikleri, karakterler, olay örgüleri, folklor unsurları ve daha birçok yönden yerel özellikleri içinde barındırarak, adaya has sözlü edebi kültürü devam ettirmektedir. Gagavuz Türk halk masallarına bakıldığında da Anadolu masallarıyla büyük benzerlikler taşıdıkları görülmektedir. Ortodoks Hristiyan Gagavuzların hem Anadolu hem de geçmiş Türk kültürüyle bağlarını koparmadığı ve buradan beslendiği yapılan çalışmalarla ortaya konulmuştur. $\mathrm{Bu}$ çalışmada Kıbrıs ve Gagavuz Türk kültürünün toplumsal bilinçaltını içinde muhafaza eden masalların tarih boyunca sağladığı birikimin kadın tipolojisine nasıl yansıdığı tespit edilmeye çalışılmıştır. Ayrıca Kıbrıs ve Gagavuz Türk toplumlarının masallar yoluyla kadına bakış açısı, kadının toplumdaki işlevleri, rolleri ve genel görünüşü de belirlenmeye gayret gösterilmiştir. Masallar âdeta söylenemeyenlerin söylendiği, yapılamayanların yapıldığ 1 serbest bir alan gibidir. Dolayısıyla toplumun kadına bakış açısını ve kadın algısını da bütün çıplaklığıyla ortaya koyan metinlerdir. Çalışmada nitel araştırma yöntemi ve verileri elde etmek için doküman analizi tekniği kullanılmıştır. Çalışmanın örneklemini ise amaçlı örnekleme yöntemiyle her iki kültürden seçilen 20'şer masal oluşturmaktadır. İnceleme kısmında masallar "betimsel analiz" yöntemiyle çözümlenmiştir. Elde edilen sonuçlara bakıldığında masal tiplerinin en fazla kişilik özellikleriyle anlatılarda yer aldığı belirlenmiş ve kadının masalların olay örgüsünü doğrudan etkileyen rollerde konumlandırıldığı görülmüştür. Ayrıca Kıbrıs ve Gagavuz Türk halk masallarında kadının iyi bir anne, çalışkan, akıllı, yetenekli bir kadın, saygı ve sevgi duyulan bir eș konumunda olduğu görülmüștür.
\end{abstract}

Anahtar Kelimeler: Masal, sosyo-kültürel rol, Kuzey Kıbrıs Türk Cumhuriyeti, Gagavuz, kadın kahraman.

* Doç. Dr., Yakın Doğu Üniversitesi, Fen Edebiyat Fakültesi, Türk Dili ve Edebiyatı Bölümü, Lefkoşa, ORCID: orcid.org/0000-0003-3968-9207, burak.gokbulut@neu.edu.tr

** Doç., Dr., Yakın Doğu Üniversitesi, Atatürk Eğitim Fakültesi, Türkçe Öğretmenliği Bölümü, Lefkoşa, ORCID: orcid.org/0000-0002-9196-1805, mustafa.yeniasir@neu.edu.tr 
BURAK GÖKBULUT - MUSTAFA YENIASIR

\title{
FEMALE CHARACTERS IN CYPRIOT AND GAGAUZIAN TURKISH FOLK TALES AND THEIR SOCIO-CULTURAL ROLES
}

\begin{abstract}
Folk tales of Cypriot Turks have several local features such as dialect properties, characters, plots, folkloric elements and others, and maintain literature culture which is unique to the island. An examination of Gagauzian Turkish folk tales shows that they have several features in common with Anatolian folk tales. Studies have shown that Orthodox Christian Gagauzians maintain their relations with both Anatolia and their past Turkish culture and fed from these sources. This paper attempts to determine the manner with which the accumulation kept by folk tales throughout history which preserve the social sub-conscious of Cypriot and Gagauzian Turkish culture is reflected on female typology. In addition, effort has been paid to identify the functions, roles and general outlook of women and the attitude of the society towards women in Cypriot and Gagauzian Turkish communities through folk tales. Folk tales are like areas of liberty where the unspeakable is spoken and undoable is done. For this reason, they are texts which display the social attitude towards and perception of women without hiding anything. In this study qualitative research method and document analysis technique was used in order to obtain the data. The sample of the study consisted of 20 tales from each culture which were chosen using purposive sampling method. In the examination section the folk tales are examined using "descriptive analysis" method. An overview of the obtained results shows that folk types are mostly found in narratives with personality features and that women are placed in roles which directly affected the plot of the folk tales. In addition, it has been witnessed that in Cypriot and Gagauzian Turkish folk tales women are in the position of good mothers, hardworking, intelligent and skilled women, and loved and respected wives.
\end{abstract}

Keywords: folk tale, social-cultural role, Turkish Republic of Northern Cyprus, Gagauzian, female character.

\section{Giriş}

Masallar bir toplumun anlayışını yansıtan, psikolojik, sosyal, kültürel ve sosyolojik halk bilgisi ürünlerdir. Masallar bazı araştırmacılar tarafindan toplumun bilinçaltını yansıtan metinler olarak da kabul edilmişlerdir. ${ }^{1} \mathrm{Bu}$ manada masallardan birçok önemli veriyi elde etmek

${ }^{1}$ Ritamani Das, "Psychoanalytical Study of Folktale", IOSR Journal of Humanities and Social Science, Cilt 19, Say1 10, 2014, s. 17. 


\section{KIBRIS VE GAGAVUZ TÜRK MASALLARINDAKİ KADIN KAHRAMANLAR VE SOSYO-KÜLTÜREL ROLLERI}

mümkündür. Kıbrıs ve Gagavuz Türk halkının masalları da yerel ve evrensel unsurları içinde barındıran önemli kültür ürünleri sayılabilirler.

Kıbrıs Türklerinin tarih içindeki seyrine bakıldığında 1571'de Osmanlı İmparatorluğunun Kıbrıs adasını fethiyle, büyük çoğunluğu Anadolu'dan adaya iskân edilen bir halk olduğu görülmektedir. Tabi ki adaya iskân edilen halk zaman içerisinde yerel kaynaklardan da beslenerek kendine has bir kültür yaratmış ve buna paralel olarak halk anlatılarını şekillendirmiş ve üretmiştir. Yaratılan kültür Osmanlı öncesinde tarih boyunca adada yaşamış olan çeşitli kültürlerden de etkilenmiş ve bu durum sözlü halk bilgisi ürünlerine de yansımıştır. Ancak halk anlatılarının genel karakteri Türkiye halk masallarıyla benzerlikler göstermektedir.

Gagavuzlar Moldova Cumhuriyeti Gagavuz Yeri Özerk Bölgesi yanında Moldova, Ukrayna, Rusya, Beyaz Rusya, Türkiye, Azerbaycan, Kazakistan, Özbekistan, Türkmenistan, Yunanistan, Romanya ve Bulgaristan gibi ülkelerde de dağınık olarak yaşamaktadırlar. Çalışmada incelemeye tabi tutulan masallar Rabia Uçkun tarafindan Moldova Cumhuriyeti Gagavuz Yeri Özerk Bölgesinde halktan derlenmiş, bir kısmı da yayınlanmış masallardan seçilip araştırmacının doktora tezine alınmış metinlerdir. ${ }^{2}$ Gagavuz Türk halk masallarının geneline bakıldığında Anadolu'yla büyük benzerlikler taşıdığı görülmektedir. Gagavuz Türklerinin kökeni ve nereden geldiği ile ilgili çeşitli görüşler olmasına karşın genel görüş Karadeniz üzerinden bölgeye gelen Oğuzların veya Anadolu'dan gelen Selçukluların torunları oldukları görüşüdür. ${ }^{3}$ Masallara bakıldığında Gagavuzların Türk kökeniyle olan bağları görülebilmektedir. Gagavuz Türk halk masalları hem İslamiyet öncesi Türk kültürüyle hem de İslamiyet sonrası Anadolu kültürüyle birçok benzerlik taşımaktadır.

Türk halk edebiyatında anlatı esasına dayanan türler önemli bir yer tutmaktadır. Bunlar içinde en önemli olanlar masallar, destanlar ve halk hikâyeleridir. ${ }^{4}$ Çalışmanın esas konusunu oluşturan masallar zaman ve

2 Rabia Uçkun, Gagauz Masallarının Tip ve Motif Yapısı Bakımından İncelenmesi, Ege Üniversitesi Sosyal Bilimler Enstitüsü, Yayımlanmamış Doktora Tezi, Danışman: Prof. Dr. Fikret Türkmen, İzmir 2003.

${ }^{3}$ Uçkun a.g.e., 60-61; Valentina Perçemli, Gagauz Türklerinde Doğum, Evlenme ve Ölüm Âdetleri, Ege Üniversitesi Sosyal Bilimler Enstitüsü, Yayımlanmamış Doktora Tezi, Danışman: Prof. Dr. Kemal Yüce, İzmir 2011, s. 7.

${ }^{4}$ Fikret Türkmen, Âşık Garip Hikâyesi Üzerinde Mukayeseli Bir Araştırma, Akçağ Yayınları, Ankara 1995, s. XI. 
mekân kavramları konusunda belirsizliği barındırmaktadır. Yani masalda gerçek mekânlar ve olayın geçtiği gerçek zaman belirsizdir. Bunun yanında masaldaki tiplere bakıldığında gerçek ve olağanüstü karakterleri içinde barındırdığı görülmektedir. Ancak bu gerçek karakterler romandaki gibi çok katmanlı veya çok yönlü değildirler. Genellikle masalda yer alan bir karakter tek yönüyle masalda yer alır ve psikolojik bir derinliği bünyesinde bulundurmaz. Tek boyutlu bu karakterler çeşitli davranışlar gösterirler ve bu davranışların sonunda masal olaylarını şekillendirirler. Kadın karakterler de aynı şekilde (anne, kız çocuk, üvey anne, kardeş, abla, peri kızı, cadı kadın vb.) tek yönleriyle öne çıkarlar ve bu çerçevede masalda yer alırlar. Ancak bu tek yönlü yapılarıyla bile birçok olayı üstlenirler ve masalı şekillendirirler.

Türk halk edebiyatının geneline bakıldığında masallarda, halk hikâyelerinde, destanlarda kadının yer aldığını ve güçlü kadınların çoğunlukla bu eserlerde rol aldığ 1 görülmektedir. ${ }^{5}$ Örneğin, Dede Korkut Hikâyelerinde kadın, toplumun temel taşlarından biri durumundadır ve ailede önemli bir yeri vardır. Bu hikâyelerde çok güçlü kadın tipler yer almaktadır. $^{6}$

Kadın kavramının sosyolojik ve kültürel boyutu değerlendirildiğinde çok geniş kapsamlı bir bilgi birikimiyle karşılaşılır. $\mathrm{Bu}$ bilgi birikimi içinde kadının sosyal rolleri, toplum ve aile içindeki yeri/işlevleri, psikolojik derinliği ve hayata karşı tavrıyla karşılaşılır. Kadının Türk toplumu içindeki yeri Türklerin Arap/İslam kültürüne geçişiyle zaman içerisinde farklı bir boyuta ulaşmaktadır. Şaman ve göçebe Türk toplumlarında kadının toplumdaki yeri ve sosyal rolleri oldukça önemli iken ${ }^{7}$ İslami daireye girişinin ardından bu durum oldukça farklılaşır. İslami kültürün hâkim olmaya başlamasından sonra kadınların sosyal hayatı eskiye göre kısıtlanmaya başlamaktadır. ${ }^{8}$

Türk toplumunun genel aile yapısına bakıldığında ataerkil bir yapıda olduğu görülmektedir. Ancak bu ataerkil yapı kadını geri plana itmez. Aksine kadın, erkeğin yanındadır ve toplumda önemli görevleri ile işlevleri

5 Abdülkadir İnan, "Türk Mitolojisinde ve Halk Edebiyatında Kadın”, Makaleler ve Incelemeler, Türk Tarih Kurumu Yayınları, Ankara 1998, s. 274-280.

${ }^{6}$ Muharrem Ergin, Dede Korkut Kitabı, Boğaziçi Yayınları, İstanbul 2017.

7 İbrahim Tellioğlu, "İslam Öncesi Türk Toplumunda Kadının Konumu Üzerine", Atatürk

Üniversitesi Türkiyat Araştırmaları Enstitüsü Dergisi, Sayı 55, 2016, s. 209-224.

${ }^{8}$ Ayfer Yılmaz, “Türk Kültüründe Kadın”, Milli Folklor, Cilt 16, Sayı 61, 2004, s. 115. 


\section{KIBRIS VE GAGAVUZ TÜRK MASALLARINDAKİ KADIN KAHRAMANLAR VE SOSYO-KÜLTÜREL ROLLERI}

vardır. ${ }^{9}$ Adaya iskân edilen ve ada kültürüyle de yoğrulan Kıbrıs Türk toplumlarında da durum böyledir. Tıpkı Türk destanlarındaki ${ }^{10}$ ve Dede Korkut Hikâyelerindeki ${ }^{11}$ gibi Kıbrıs ve Gagavuz Türk toplumlarında da kadının yeri oldukça önemli ve vazgeçilmezdir.

\section{Araştırmanın Metodolojisi}

\subsection{Araştırma Modeli}

$\mathrm{Bu}$ araştırmada nitel yaklaşıma uygun olarak veri toplanmıştır. Nitel araştırma, "gözlem, görüşme ve doküman analizi gibi nitel veri toplama yöntemlerinin kullanıldığı, algıların ve olayların doğal ortamda gerçekçi ve bütüncül bir biçimde ortaya konmasına yönelik nitel bir sürecin izlendiği araştırma olarak tanımlanabilir". ${ }^{12}$ Verileri toplamak amacıyla doküman analizi tekniği kullanılmıştır.

\section{2 Çalışmanın Örneklemi}

Çalı̧̧manın evreni, örneklem amaçlı örnekleme yöntemiyle seçilen $40(20+20)$ masaldan oluşmaktadır. Amaçlı örneklemenin bir türü olan kolay ulaşılabilir örnekleme bu çalışmada temel alınmış, böylelikle araştırmacıların önceden incelediği, bilgi sahibi olduğu ve içinde kadınla ilgili unsurların bulunduğunu düşündüğü 40 masal tercih edilmiştir.

Kıbrıs Türk halk masalları (20 masal) Oğuz Yorgancığglu'nun Kibrıs Türk Folklorundan Derlemeler-Masallar $\mathrm{II}^{13}$ adlı kitabından alınmıştır. Yorgancıoğlu masalları halktan derleyerek yayınlamıştır.

\footnotetext{
9 Mehmet Mandaloğlu, “İslamiyet’ten Önce Türklerde Aile Hukuku”, Selçuk Türkiyat Araştırmaları Dergisi, Cilt 1, Sayı 33, 2013, s. 155-156.

${ }^{10}$ Metin Ekici, “Anadolu Sahası Köroğlu Anlatmalarında Kadın Tipler”, Millî Folklor, Cilt 6, Say1 44, 1999, s. 10-17.

${ }^{11}$ Metin Ekici, "Dede Korkut Kitabında Kadın Tipleri”, Ed. Birgül, A. K., Canpolat, A. Ş. Uluslararası Dede Korkut Bilgi Şöleni Bildiri Kitabı, Atatürk Kültür Merkezi Başkanlığı Yay., Ankara, 2000, ss. 123-138; Aysun Sadıç, Masallarda Kadın-Güneydoğu Anadolu ve Doğu Karadeniz Masal Örnekleri, Gaziantep Üniversitesi Sosyal Bilimler Enstitüsü, Yayımlanmamış Yüksek Lisans Tezi, Danışman: Yrd. Doç. Dr. Behiye Köksel, Gaziantep 2008.

12 Ali Yıldırım ve Hasan Şimșek, Sosyal Bilimlerde Nitel Araştırma Yöntemleri, Seçkin Yayıncilık, Ankara 2006, s. 45.

13 Oğuz Yorgancioğlu, Kıbrıs Türk Folklorundan Derlemeler-Masallar II, Canbulat Yayınevi, Mağusa 2006.
} 
Çalışmada incelenen Kıbrıs Türk halk masalları şunlardır: Sihirli Tencere (113-115), Güvercin Şehzade (152-153), Merdane (8-10), Sen Neysen Osun (158-159), Hamur Kız (103-104), Cadaloz (178-180), Dokumac1 Kız (7882), Açıkgöz Kadın (209-210), İlahim Damın Aksın Da Kazanın Altına Saklanasın (56-57), Ne Yapsan Damar Çeker (5-7), Akıldane (10-13), Gecegezen (30-31), Yemeyenin Yiyicisi Vardır (37-39), Dilsiz Şahit (4755), Dilencinin Kızı (136), Fislikâncı (Fesleğen) Güzeli (207-208 ), Sabreden Derviş, Muradına Ermiş (85-86), İki Kız Kardeş (75-78), Dünya Güzeli (89-92), Dürdane (111-112).

Gagavuz Türk halk masalları ise Rabia Uçkun'un Gagavuz Masallarının Tip ve Motif Yapısı Bakımından İncelenmesi ${ }^{14}$ adlı yayınlanmamış doktora tezinden alınmıştır. Çalışmada incelenen Gagavuz Türk halk masalları (20 masal) ise şunlardır: Ayı hem Tilki (412-413), Trakalı Öküz (416-418), Üvey Anne ile Kızı (424-425), Kaplumbağa Kız (466-467), Kıza Âşık Olan Güneş (483-484), Hain Kardeş (485-486), Vaftiz Evlat (486-491), Gençlikte mi Kocalıkta mı? (494-495), Hoburdan Kurtulan Akı1lı Kız (513), Pitıraş (520-529), Kim Taa Gözäl (530-531), Öküze Dönüşen Çocuk (531-533), Altın Yumurtlayan Tavuk (543-544), İki Moçuga (545-547), Babası ile Evlenmek İstemeyen Kız (549-551), Balıç̧ı Oğlu (551-554), Papaz ile Kızı (565-566), Üç Kız Kardaş (566-568), İi Ürektä Ool (579-581), İyi Huylu Karısı Sayesinde Zengin Olan Adam (610611).

\subsection{Veri Toplama ve Analiz Yöntemi}

Çalışmanın verilerini elde etmede 20 Kıbrıs Türk halk masalı ve 20 Gagavuz Türk halk masalı kullanılmıştır. Araştırmada betimsel analiz yoluyla masallar çözümlenmiş, ardından kadın kavramıyla ilgili unsurlar tematik bir çerçevede yorumlanarak verilmiştir.

\section{4 Çalışmanın Amacı}

Araştırmada Kıbrıs ve Gagavuz Türk toplumlarının masallar yoluyla kadına bakış açısını, kadının toplumdaki işlevlerini, rollerini, genel görünüşünü belirlemek ve buradan hareketle genel kadın tipolojisini karşılaştırmalı bir bakış açısıyla ortaya koymak amaçlanmaktadır. $\mathrm{Bu}$ amaçla aşağıda verilen soruların cevapları aranmıştır:

\footnotetext{
${ }^{14}$ Uçkun, a.g.e.
} 


\section{KIBRIS VE GAGAVUZ TÜRK MASALLARINDAKİ KADIN KAHRAMANLAR VE SOSYO-KÜLTÜREL ROLLERI}

a. Kıbrıs ve Gagavuz Türk halk masallarında kadın tipleri, işlevleri ve rolleri nelerdir?

b. Kıbrıs ve Gagavuz Türk halk masallarında kadın algısı nasıldır ve kadının ailedeki ve toplumdaki yeri nedir?

\section{Bulgular}

Bulgular kısımda her iki toplumun masallarında yer alan kadın tipleri ve kadın ile ilgili çeşitli unsurlar incelenmiş, masallarda tespit edilen kadın tiplerin oranları sunulmuş ve kadının nasıl yer aldığı çeşitli açılardan değerlendirilmeye çalışılmıştır.

\subsection{Kadın Karakterlerle İlgili Sayısal Veriler}

Tablo 1. Masallarda yer alan kadın karakterlerin kavramsal kategorileri

\begin{tabular}{|c|c|c|c|c|c|c|}
\hline Kategori & $\begin{array}{c}\text { Kuzey Kıbrıs } \\
\text { Kategori Kapsamındaki Tipler }\end{array}$ & $\mathbf{F}$ & $\%$ & $\begin{array}{c}\text { Gagavuz } \\
\text { Kategori Kapsamındaki } \\
\text { Tipler }\end{array}$ & $\mathbf{F}$ & $\%$ \\
\hline Kişilik & $\begin{array}{c}\text { İyi Anne (5), Kötü Üvey Anne } \\
\text { (3), Çalışkan Kadın (3), Paragöz } \\
\text { (3), Kocasına Saygılı Kadın (3), } \\
\text { Kıskanç Kaynana (3), Güçlü } \\
\text { Karakterde Kız Çocuk (2), Güçlü } \\
\text { Karakterde Kocakarı (2), Kıskanç } \\
\text { Kız kardeş/Abla (4), Yetenekli } \\
\text { Kadın ve Kız (2), Otoriter Kadın } \\
\text { (2), Dırdırcı Kadın (2), Pinti } \\
\text { Kadın (1), Dürüst Kadın (1), } \\
\text { Çocuklarını Öldürmek İsteyen } \\
\text { Kötü Anne (1), Annesini Öldüren } \\
\text { Kötü Kız (1), Hayvan Sever Kız } \\
\text { (1), Sahtekâr Kadın (1), İffetsiz } \\
\text { Kadın (1), Hazır Cevap Kız (1), } \\
\text { Sabırlı Kız (1), Kötü Halayık Kız } \\
\text { (1), Kocasına Saygısız Kadın (1), } \\
\text { Kötü Denizkızı (1), Cadaloz } \\
\text { Kocakarı (1), Kibirli Kız (1). }\end{array}$ & 48 & 240 & $\begin{array}{c}\text { İyi Anne (1), Kötü Üvey } \\
\text { Anne (8), Çalıskan Kadın } \\
\text { (1), Kocasına Saygılı } \\
\text { Kadın (1), Kıskanç Kız } \\
\text { Kardeş-Abla (2), } \\
\text { Yetenekli Kadın ve Kız } \\
\text { (1), Otoriter Kadın (2), } \\
\text { Dırdırıı Kadın (1), } \\
\text { Çocuklarını Öldürmek } \\
\text { İsteyen Kötü Anne (1), } \\
\text { Sahtekâr Kadın-Kız (3), } \\
\text { İffetsiz Kadın-Kız (2), } \\
\text { Kötü Kız (2), Akıllı kız } \\
\text { (2), Yardımıı Kadın (1), } \\
\text { Kötü Kız Kardeş (1), } \\
\text { Kötü Üvey Kız Kardeş } \\
\text { (1), Cadı Kadın (2), } \\
\text { Güçlü Kız (1), Kötü Anne } \\
\text { (1), Yardımıı Kadın (1), } \\
\text { Saygısız Kadın (1), Eşine } \\
\text { Sadık Kadın (1), Vefalı } \\
\text { Kadın (1). }\end{array}$ & 38 & 190 \\
\hline Statü & $\begin{array}{l}\text { Dul Kadın (7), Yaşlı Kadın (5), } \\
\text { Fakir Kadın ve Kız (3), Zengin } \\
\text { Kız/ Kadın (2), Padişah Kızı (2), }\end{array}$ & 21 & 105 & $\begin{array}{c}\text { Dul Kadın (1), Yaşlı } \\
\text { Kadın (1), Fakir Kadın ve } \\
\text { Kız (1), Padişah Kızı (3), } \\
\text { Padişah eşi (1), Papaz }\end{array}$ & 9 & 45 \\
\hline
\end{tabular}


BURAK GÖKBULUT - MUSTAFA YENIAASIR

\begin{tabular}{|c|c|c|c|c|c|c|}
\hline & Vezir Karıı (1), Öksüz Kız (1). & & & Kızı (1), Çingene (1). & & \\
\hline $\begin{array}{c}\text { Fiziki } \\
\text { ozellikler }\end{array}$ & Güzel Kadın (7), Çirkin Kız (1). & 8 & 40 & Güzel Kadın-Kız (4). & 4 & 20 \\
\hline Meslek & $\begin{array}{c}\text { Büyücü Kadın (1), Çoban Kadın } \\
\text { (1), Ebe Kadın (1), Ciftçi Kadın } \\
\text { (1), Hizmetkâr Kız (1), } \\
\text { Dokumacı Kız (1). }\end{array}$ & 6 & 30 & $\begin{array}{c}\text { Kenevir İşçisi (1), Terzi } \\
\text { (1), Kenevir Kumaş } \\
\text { Dokumacı (1), Yapağ1 } \\
\text { İşleyici (1). }\end{array}$ & 4 & 20 \\
\hline
\end{tabular}

Tablo 1'de, incelenen Kıbrıs Türk halk masallarında yer alan tiplerin kavramsal kategorilerine bakıldığında Kişilik (\% 240)'le ilgili kategorinin en yüksek oranda olduğu görülmektedir. Bu da göstermektedir ki masallarda kadın karakterler en fazla kişilik özellikleriyle yer almaktadır. Kişilik kategorisinde en yüksek oranda bulunan iyi anne tipidir. Statü ise \% 105 'lik oranla ikinci sırada yer almaktadır. Statü kavramında kadının toplum içindeki konumu esas alınmıştır. Bu kategoride en yüksek oranda bulunan tip dul kadındır. Tabloda üçüncü sıradaki kategori Fiziki Özellikler (\% 40) kategorisidir. Burada kadınların dış görünüşlerine göre bir gruplandırma yapılmıştır. Bu kategoride güzel kadın birinci sıradadır. Son kategori ise \%30'luk oranla Meslek kategorisidir. Kişilik kategorisinde yer alan denizkızı ve cadaloz karakterleri masallarda yer alan iki gerçeküstü kadın karakterdir. Kıbrıs Türk kültüründe cadaloz korkutucu görünüşü olan olağanüstü bir kadın tipidir.

Tablo 1'de, incelenen Gagavuz Türk halk masallarında yer alan tiplerin kavramsal kategorilerine bakıldığında ise burada da Kişilik (\% 190)'le ilgili kategorinin en yüksek oranda olduğu görülmektedir.

Kişilik kategorisinde en yüksek oranda bulunan kötü üvey anne tipidir. Statü de Kıbrıs Türk halk masallarındaki gibi ikinci sırada yer almaktadır (\% 45). Bu kategoride en yüksek oranda bulunan tip padişah kızıdır. Burada Kıbrıs Türk halk masallarından farklı olarak Fiziki Özellikler (\% 20) ve Meslek kategorileri aynı oranlardadır (\% 20). Fiziki Özellikler kategorisinde tek bir tip bulunurken Meslek kategorisinde aynı oranda dört farklı tip bulunmaktadır.

Gagavuz Türk halk masallarında Kişilik kategorisinde yer alan cad kadın ise tipi ise Gagavuz masallarında yer alan gerçeküstü bir kadın karakterdir. 


\section{KIBRIS VE GAGAVUZ TÜRK MASALLARINDAKİ KADIN KAHRAMANLAR VE SOSYO-KÜLTÜREL ROLLERI}

\subsection{Kadın Karakterlerle İlgili Analiz ve Değerlendirmeler}

\subsubsection{Gagavuz ve Kıbrıs Türk halk masallarında yer alan kadınların aile içerisindeki yeri ve önemi}

2.2.1.1. Gagavuz ve Kıbrıs Türk halk masallarında karı-koca ilişkilerinin durumu: İncelenen 20 masalda bulunan kadın karakterlere bakıldığında kadın karakterlerin aile içinde önemli ve saygıdeğer bir yeri olduğu görülmektedir. Kadınların aile içinde sözü geçmekte ve kocaları tarafından düşünceleri önemsenmektedir. Örneğin; Açıkgöz Kadın masalında erkek, eşinin sözünü dinlemektedir: "Kadın bir gün demiş kocasına benim aklıma böyle böyle bir fikir geldi. Kabul edersen biraz rahat yaşarız, dedi. Adam da kabul etti." ${ }^{15}$

İncelenen 20 Gagavuz masalında bulunan kadın karakterlere bakıldığında da Kıbrıs Türk masallarında olduğu gibi kadın karakterlerin aile içinde önemli ve saygın bir yeri olduğu söylenebilir. Masalların geneline bakıldığında kadın tiplerin, masallarda sözü geçen ve eşleri tarafından dinlenen karakterler olduğu görülmektedir. Örneğin; "Ayı hem Tilki" masalında adam ayı tarafından cezalandırılacağını bilse de karısının isteği üzerine kumaş ve balı nereden bulduğunu anlatır ve eşini kırmamak için onun sözüne uyarak olanları söyler. Yine aynı masalda adam karısını düşünerek tilkinin postundan ona bir kaban yaptırır ve mutlu olmasını sağlar. ${ }^{16}$

Kıbrıs Türk masallarında yer alan kadınların, kocaları karşısında kendilerini savunan ve düşüncelerini söylemekten korkmayan kadınlar olduğu görülmektedir. Örneğin; Sihirli Tencere masalında kadın, tencereyi padişahın adamlarına kaptıran kocasına karşı sözünü çekinmeden söylemektedir: "Kocakarı başlamış dırdırlansın buna. İşin gücün yok illa ki herkesleri yedireceksin ha. Aha böyle adamın elinden alırlar da aç kalırsın. İhtiyar bakmış, kocakarı haklı, demiş ki, kim aldı tencereyi?" 17 Feslikancı Güzeli masalında da kadın, eşine düşüncesini ifade etmektedir: "Terzi, olanı biteni anlatmış, bir çare bulmazsa başının belâya gireceğini söylemiş. Karısı: Maraz ettiğin şeye bak demiş, açık açık diyeceksin ona, mermerden esvap olmaz, diye." ${ }^{18}$ Merdane masalında da oğlunun gelin olarak getirdiği kızı,

\footnotetext{
${ }^{15}$ Yorgancioğlu, a.g.e., s. 209.

${ }^{16}$ Uçkun, a.g.e., s. 412.

${ }^{17}$ Yorgancioğlu, a.g.e., s. 113.

${ }^{18}$ Yorgancioğlu, a.g.e., s. 207.
} 


\section{BURAK GÖKBULUT - MUSTAFA YENİASIR}

padişahın karısı onaylamakta ve padişah, kızı ancak bu şekilde kabul etmektedir: "Padişahım, demiş kocasına. Bu kız Allah'ın bize nimetidir. Oğlumuza verelim."19

Gagavuz masallarında yer alan kadınların, eşleri tarafından sözleri dinlenen ve söz söyleyen kadınlar olduğu görülmektedir. Örneğin; P1tıraş masalında adam karısının telkiniyle evden ayrılarak para kazanmaya gider ve döndüğünde yaptığı planları karısına da anlatır. ${ }^{20}$ Kim Taa Gözäl masalında da adam eşi istedi diye (ikinci eş-üvey anne) ilk karısından olan kızını ormana bırakır. ${ }^{21} \mathrm{Bu}$ da yine kadının aile içindeki otoriter ve etkin rolünün göstergesidir. Öküze Dönüşen Çocuk masalında da aynı durum vardır. İkinci eşin isteğiyle adam kendi çocuklarını ormana bırakır. ${ }^{22}$

Araştırmaya dâhil edilen her iki ülkenin masalları değerlendirildiğinde Kıbrıs Türk halk masallarında, Gagavuz halk masallarına nazaran kadının bir nebze daha saygın ve baskın bir rolünün olduğu söylenebilir.

İncelenen Kıbrıs Türk masallarında kocası tarafindan dövülen veya saygı duyulmayan kadına herhangi bir masalda rastlanmamıştır. Bunun aksine kocasına saygısız davranan veya onu hor gören kadın eşlere rastlanmıştır. Sen Neysen Osun masalında kadın, adama kızıp hakaret etmektedir: "Sen ne sakar, ne hayırsız adamsın. Elinden hiç bir iş gelmez. Arada eline düşen firsatları da geri tepersin. Bir karnımızı bile doyuramazsın. Keşke seninle evlenmeseydim." ${ }^{23}$ Adam da buna karşıllk hiçbir şey söylemeden sessiz kalmaktadır.

Kadının çocuklarıyla olan ilişkisine bakıldığında anne-oğul daha çok sevgi, saygı ve sadakate dayalı bir ilişki içindeyken, anne-kız ekseninde sevgi, saygı yanında bazen de çatışmaya dayalı ilişkilerin olduğu görülmektedir. Gagavuz halk masallarında da yer yer kadınların kocalarına kötülük yaptığı da görülmektedir. Örneğin Trakalı Öküz masalında kadın hasta gibi davranarak hileyle kocasını kandırır. ${ }^{24}$ Yine Altın yumurtlayan Kadın masalında bir Yahudi'nin aklına uyarak eşini ve çocuklarını kandırır.

\footnotetext{
${ }^{19}$ Yorgancioğlu, a.g.e., s. 9.

${ }^{20}$ Uçkun, a.g.e., s. 520.

${ }^{21}$ Uçkun, a.g.e., s. 530.

${ }^{22}$ Uçkun, a.g.e., s. 531.

${ }^{23}$ Yorganc1oğlu, a.g.e., s. 158

${ }^{24}$ Uçkun, a.g.e., s. 416.
} 


\section{KIBRIS VE GAGAVUZ TÜRK MASALLARINDAKİ KADIN KAHRAMANLAR VE SOSYO-KÜLTÜREL ROLLERI}

İki Moçuga masalında da fakir adam evine gider, sofra kurulmayınca karısından dayak yer. ${ }^{25}$

2.2.1.2. Gagavuz ve Kıbrıs Türk halk masallarında anne-oğul ilişsilerinin durumu: Kıbrıs Türk halk masallarında geçen anne-oğul ilişkisinde annelerin çoğunlukla oğullarıyla iyi ilişkileri olduğu görülmektedir. Anneler oğulları için sevgi duyup emek verirken oğulların da annelerini sevdikleri, onlara saygı duydukları ve sözlerini dinledikleri görülmektedir. Ne Yapsan Damar Çeker masalında eşini kaybeden kadın çok zorluk çekmesine rağmen oğlunu üvey babaya koymamak, zarar görmesini engellemek için evlenmez ve oğlunu kendi başına iyi bir şekilde yetiştirir. ${ }^{26}$ Merdane masalında da anne, oğlu için iyi bir eş seçmeye çalışır ve ona iyi bir eş bulur. ${ }^{27}$ Günümüz Kıbrıs Türk toplumunda da anne, oğlunun isteğine bağlı olarak bu işlevini halen sürdürmektedir. Masalların geneli değerlendirildiğinde annenin oğlunu koruyucu kollayıcı işlevini sürdürdüğ̈̈, onun için kaygılandığı ve oğluna büyük bir sevgi duyduğu görülmektedir.

Gagavuz Türk halk masallarında da anne-oğul ilişkilerinin iyi olduğu ve annenin koruyucu rolünün burada da sürdügü görülmektedir. Örneğin Gençlikte mi Kocalıkta mı masalında kadın padişahın adamları tarafindan kaçırılır ve tekrar oğluna kavuşunca çok mutlu olup oğluna sarılır. ${ }^{28}$ Ancak Gagavuz masallarında anne-oğul ilişkisinin Kıbrıs Türk halk masallarındaki kadar belirgin ve öne çıkan bir özellik arz ettiği söylenemez. Hatta İi Ürektä Ool masalında kadın, çocuklarının oturduğu evi satıp kendileriyle birlikte yaşamayı teklif etmelerini kabul etmez ve gizlice evini satarak çocuklarına buradan kazandığı parayı kaybettiğini söylemesi üzerine çocukları onu evden kovar. $^{29}$

2.2.1.3. Gagavuz ve Kıbrıs Türk halk masallarında anne-kız ilişkilerinin durumu: Kıbrıs Türk halk masallarındaki anne kız ilişkisine bakıldığında annenin burada koruyucu kollayıcı özelliğini sürdürdüğü, kızının iyi yetişmesi için çabaladığı ve ona sevgi duyduğu görülmektedir. Ancak anne-oğul ilişkisinden farklı olarak burada belli noktalarda çatışmanın da bulunduğu söylenebilir. Dilsiz Şahit masalında anne, kızını iyi

${ }^{25}$ Uçkun, a.g.e., s. 545.

${ }^{26}$ Yorgancioğlu, a.g.e., s. 5.

${ }^{27}$ Yorganc1oğlu, a.g.e., s. 9.

${ }^{28}$ Uçkun, a.g.e., s. 494.

${ }^{29}$ Uçkun, a.g.e., s. 579. 
yetiştirmek ve düzgün biriyle evlendirmek için uğraşırken, kız gizlice bir erkekle görüşür ve bunun üzerine anne-kız arasında büyük bir çatışma yaşanır. Burada çatışma annenin kızını düzgün biriyle evlendirme çabasından kaynaklanmaktadır. ${ }^{30}$ Güvercin Şehzade masalındaysa annekızın iyi ilişkiler içinde olduğu görülmektedir. Anne, kızını sevip iyi yetiştirmeye çalışırken kızı da annesine ev işlerinde yardımcı olur, annesinin her dediğini gayet güzel bir şekilde yapar. ${ }^{31}$ Burada sevgi ve saygıya dayalı bir anne-kız ilişkisi görülmektedir.

Gagavuz Türk halk masallarında da anne-kız ilişkilerinin güçlü olduğu ve özellikle de üvey anne ile kendi kızlarının iyi geçinerek üvey kıza kötü davrandıkları görülmektedir. Örneğin; Kim Taa Gözäl masalında kızın annesi ineğe dönüştürülür. Böylece kızın (Gözel) babası başka bir kadınla evlenir ve üvey anne kendi kızı ile Gözel'i kıskanır ve ona kötülük yapmak ister. Burada üvey anne ve kızının iyi anlaştığı görülmektedir. Bunun yanında Gözel'in annesi ineğe dönüşüp şekil değiştikten sonra bile kızını bir şekilde korumaya devam eder. ${ }^{32}$

Üvey Anne ile Kızı masalında da üvey anne ve kızının iyi ilişkileri görülür. Masalda bir dede ile bir nine ve ilk eşlerinden kızları bulunmaktadır. Dede ile nine ikinci kez evlendiklerinde üvey anne, dedenin kızına kendi öz kızıyla birleşerek kötülük yapar. Burada anne ile öz kızının iyi ilişkileri dikkat çekmektedir. ${ }^{33}$

2.2.2. Gagavuz ve Kıbrıs Türk halk masallarında yer alan kadınların toplum içerisindeki yeri ve önemi

Bu başlıkta kadın sadece eş ve anne açısından değil farklı açılardan da değerlendirilmiştir. Günümüz Türk toplumlarında olduğu gibi, sözlü halk masallarında da kadından beklenen işler ve ona yüklenen görevler bulunmaktadır. Ancak toplumda iyi bir yer edinme kaygisı bulunmayan ve kötü rollerde bulunan kadınlar da masallarda yoğun olarak yer almaktadır.

2.2.2.1. İyi karakterli kadınlar: Toplumda iyi bir yer edinme, sosyal açıdan kabul görme ve toplumsal normlara uyabilme genel olarak tüm kadınların ve insanların hedeflerindendir. Kadının bunu yapabilmesi

\footnotetext{
${ }^{30}$ Yorgancioğlu, a.g.e., s. 47-55.

${ }^{31}$ Yorganc1oğlu, a.g.e., s. 152-153.

${ }^{32}$ Uçkun, a.g.e., s. 530.

${ }^{33}$ Uçkun, a.g.e., s. 424.
} 


\section{KIBRIS VE GAGAVUZ TÜRK MASALLARINDAKİ KADIN KAHRAMANLAR VE SOSYO-KÜLTÜREL ROLLERI}

için de toplum yapısına bağlı olarak belirli rolleri üstlenmesi gerekmektedir. Kıbrıs ve Gagavuz Türk halk masallarda da bu durumla karşılaşılmaktadır. Kıbrıs Türk halk masallarında yer alan kadınlar çalışan, eşine çocuklarına evine iyi bakan, tutumlu, akıllı bir kadın konumundadır. Gagavuz Türk halk masallarında yer alan kadınlar ise eșinin ve çocuklarının yanında olan, sadık, çalışkan kadınlardır. Örneğin İyi Huylu Karısı Sayesinde Zengin Olan Adam masalında ${ }^{34}$ padişahın kızı fakir bir delikanlı ile evlenir ve ihtiyaçlı olan eşinin iki öküz alması için fistanını ona verir.

Tarih boyunca Türk toplumunun anlayışına bakıldığında kadın, toplumda iyi bir yer edinmek için öncelikle iyi bir eş olmalıdır. İncelenen her iki ülke masallarında da kadınlar; eşlerine saygı ve sevgi duyan, evini temizleyen, yemek pişiren, çocuklarını iyi yetiştiren kadınlardır. Bunun yanında iyi bir anne olmak da bir diğer önemli husustur. İyi anne olma hususu Kıbrıs Türk halk masallarında daha belirgin ve ön plandadır.

Her iki toplumun masallarındaki kadınların bir kısmı çalışan ve üreten kadınlardır. Çiftçilik, çobanlık, dokumacılık (yünden dokuma-Kuzey Kıbrıs, kenevirden dokuma-Gagavuz), hizmetkârlık, çamaşır yıkayıcılığı, yapağıcılık (Gagavuz) kadınların bazı uğraşı alanlarıdır. Örneğin; İlahi Damın Aksın da Kazanın Altına Saklanasın masalında yaşı kadının keçikoyun karışık olmak üzere bin baş davarı vardır ve bunların tümüne yalnız başına zevkle bakan gerçek bir çobandır. ${ }^{35}$ İki Kız Kardeş masalında da her iki kız kardeş değirmende çalışmaktadır. ${ }^{36}$ Gagavuz masallarından Kim Taa Gözäl ${ }^{37}$ masalında kadın yapağ 1 işlerken Hoburdan Kurtulan Akıllı Kız ${ }^{38}$ masalında üç kız kardeş kenevirden kumaş dokurlar.

Akıllı kadın ve kızlar da incelenen masallarda sık1lıkla yer almaktadır. Akıllı ve zeki kadınlar da aile ve toplum içinde saygı duyulan söz sahibi olabilen kadınlardır. Kıbrıs Türk halk masallarından Açıkgöz Kadın, Güvercin Şehzade, Merdane ve Dilsiz Şahit masallarında akıllı ve güzel kadınlar dikkat çekmektedir. Merdane masalında oğlunun tanıştırmak için saraya getirdiği kız için annesi, "Bir içim su bu kız. Güzelliği kadar da akıllı" demektedir. ${ }^{39}$ Gagavuz Türk halk masallarında da akıllı ve zeki kızlar

\footnotetext{
${ }^{34}$ Uçkun, a.g.e., s. 610.

${ }^{35}$ Yorgancioğlu, a.g.e., s. 56-57.

${ }^{36}$ Yorgancioğlu, a.g.e., s. 76.

${ }^{37}$ Uçkun, a.g.e., s. 530.

${ }^{38}$ Uçkun, a.g.e., s. 513

${ }^{39}$ Yorgancioğlu, a.g.e., s. 10.
} 
görülür. Örneğin; Hoburdan Kurtulan Akıllı $\mathrm{K}^{40}$ masalında üç kız kardeşten en küçükleri zekâsıyla hoburdan (hortlak) kurtulmayı başarır.

Bunun yanında Kıbrıs Türk halk masallarında Allah'a inanan Müslüman kadınlar da geçmektedir. Masallarda inançlı olmak toplum tarafından kabul gören bir durumdur. Hamur $\mathrm{K}^{41}$ masalında çocuğu olmayan kadın Allah'tan bir çocuk ister ve sonunda dileği gerçekleşir. Sabreden Derviş, Muradına Ermiş ${ }^{42}$ masalında kız, Kur'an okurken başını örter. Masalda Kur'an okuyan kızın yemeni bağlaması da dine verilen önemi göstermektedir. Gagavuz Türk halk masallarında ise kadınların Hristiyanlık dinini benimsediği ve bu dinin gereklerini yerine getirdiği görülmektedir. Örneğin; Papaz ile $\mathrm{K}_{1 z}{ }^{43}$ masalında hem karısı hem de kızının Hristiyan olduğu görülmektedir. Yine İki Moçuga ${ }^{44}$ masalında kar1-koca dayaktan kurtulmak için Hristiyan bir unsur olan vaftiz babaya yalvarırlar.

2.2.2.2. Kötü karakterli kadınlar: Toplumda pek fazla kabul görmeyen ancak masallarda yer alan bazı kötü kadın tipler de bulunmaktadır. Örneğin; incelenen Kıbrıs Türk halk masallarında geçen büyücü kadın, kötü üvey anne, iffetsiz kadın, kıskanç kız kardeş, kıskanç kaynana, kötü halayık, çocuğunu öldüren kadın, annesini öldüren kız, kız kardeşlerini öldüren ablalar vs. tipler toplumda çok fazla kabul görmeyen karakterler olmalarına rağmen sözlü anlatılarda yer almaktadırlar. Gagavuz Türk halk masallarında yer alan kötü karakterler arasında; kötü üvey anne, kıskanç kız kardeşler, çocuklarını öldürmek isteyen kötü anne, sahtekâr kadın-kız, iffetsiz kadın, kötü üvey kız kardeş, cadı kadın, saygısız kadın yer almaktadır.

Masallardan yola çıkarak kötü kişilere bakıldığında farklı karakterle karşılaşılmaktadır. Örneğin; Kıbrıs Türk halk masallarından Sabreden Derviş, Muradına Ermişs ${ }^{45}$ masalında kötü halayık, masaldaki başkahraman olan kızın elinden evleneceği adamı dalavereyle alır ve kızı kandırır. İki Kız Kardeş $^{46}$ masalında da kardeşlerden biri diğerinin kızını kıskanmakta ve kıza elinden gelen bütün kötülüğü yapmaktadır. Fislikancı Güzeli masalında

\footnotetext{
${ }^{40}$ Uçkun, a.g.e., s. 513.

${ }^{41}$ Yorgancioğlu, a.g.e., s. 103.

${ }^{42}$ Yorgancioğlu, a.g.e., s. 85.

${ }^{43}$ Uçkun, a.g.e., s. 565.

${ }^{44}$ Uçkun, a.g.e., s. 545.

${ }^{45}$ Yorgancioğlu, a.g.e., s. 85-86.

${ }^{46}$ Yorgancioğlu, a.g.e., s. 76-78.
} 


\section{KIBRIS VE GAGAVUZ TÜRK MASALLARINDAKİ KADIN KAHRAMANLAR VE SOSYO-KÜLTÜREL ROLLERI}

da iki abla küçük kız kardeşlerini kıskanmakta ve onu öldürmektedirler. ${ }^{47}$ Bu tip karakterlerin birçoğu gerçek hayatta da var olabilen kötü kişilerdir.

Gagavuz Türk halk masallarından Hain Kardeş ${ }^{48}$ masalında kız bir devle ilişkiye girmekte ve devin isteğiyle abisine tuzak kurarak hainlik etmektedir. Vaftiz Evlat ${ }^{49}$ masalında ise evlerine gelen misafirin yaralarına iyi geleceği için çocuklarını fırında yakmayı kabul eden bir anneyle (ve babayla) karşılaşırız. Altın Yumurtlayan Tavuk masalında yumurtaları satın almaya gelen Yahudi'nin kadının aklını çelmesi üzerine kadın tavuğu keser ve çocuklarını evden kovarak kocasını da bu konuda yalan söyler.

\subsubsection{Masallarda öne çıkan bazı kadın karakterler}

İncelenen masallarda yer alan bazı dikkat çekici karakterler arasında güçlü, güzel, çalışkan, dul ve iffetsiz kadın ile kıskanç-kötü kaynana ve üvey anne bulunmaktadır.

2.2.3.1. Güçlü kadınlar: Güçlü kadınlar incelenen Kıbrıs ve Gagavuz Türk halk masallarında çok kez karşımıza çıkmaktadır. Güçlü eşler ve kızlar; evine, eşine ve çocuklarına bakan, gerektiğinde çalışan ve kocalarının karşısında duran kadınlardır. Bugünkü Kıbrıs ve Gagavuz Türk toplumlarında da güçlü bir kadın potansiyeli bulunmakta ve bu da toplumun ileriye taşınmasına, modernleşmesine ve gelişmesine büyük katkı sağlamaktadır.

2.2.3.2. Güzel kadınlar: Güzel kadınlar da her iki toplumun masallarında sıklıkla yer almaktadır. Ancak güzellik yanında akıl ve zekâ da önemlidir ve masallarda sadece güzel değil, zeki ve akıllı kadın olmak da önemlidir.

2.2.3.3. Çalışkan kadınlar: Dul kadın tipi de Kıbrıs ve Gagavuz Türk toplumlarının gerçeğini yansıtmaktadır. Kıbrıs ve Gagavuz Türk kadını geçmişte evine ve çocuklarına en iyi şekilde bakarken bir taraftan da çiftçilik, çobanlık ve dokumacılık gibi mesleklerle uğraşmış güçlü kadınlarıdır. $\mathrm{Bu}$ anlamda masallarda da çalışan kadınların geçmesi aslında toplumsal yapının bir yansımasıdır. Günümüz Kıbrıs ve Gagavuz Türk

\footnotetext{
${ }^{47}$ Yorgancioğlu, a.g.e., s. 207-208.

${ }^{48}$ Uçkun, a.g.e., s. 485

${ }^{49}$ Uçkun, a.g.e., s. 486.
} 
toplumlarında da kadın; çalışan, üreten ve topluma-ailesine destek olan bir konumdadir.

2.2.3.4. Dul kadınlar: Dul kadın olmak bazı toplumlarda kabul görmezken incelenen masallarda dul kadınların genellikle horlanmadığı görülmektedir. $\mathrm{Bu}$ masallarda geçen dul kadınlar kendi ayakları üzerinde durabilen, çalışan, çocuklarına bakan güçlü kadınlardır. Örneğin; Gagavuz Türk halk masallarından Hırsızlık ${ }^{50}$ masalında oğluyla yaşayan ona destek olan dul bir kadın dikkat çekmektedir. Yalnızca Kıbrıs Türk halk masallarından Hamur Kız masalında geçen dul kadın horlanmaktadır: "Kadın dul kalmış. Başlamış etrafta bir dedikodu. Yok, öyle yaptı, yok böyle yaptı. Çocuğu da yok. Onun için her önüne gelen bir yalan uydurur." ${ }^{51}$ Günümüz Kıbrıs ve Gagavuz Türk toplumunda dul kadın olmak ters karşılanmamakta ancak tekrar evlenip aile kurması konusunda üstü kapalı bir baskı hissettirilmektedir.

2.2.3.5. Kıskanç ve kötü kaynanalar: Kıskanç ve kötü kaynana Kıbrıs Türk sosyal yaşamında sıklıkla karşımıza çıkan bir tiptir ve bu tip incelenen masallara da yansımıştır. Kötü kaynana gelinine karşı oğlunu kıskanan ve gelinine kötülükler yapan bir tiptir. Kıbrıs Türk halk masallarından Dokumacı Kız ve Dünya Güzeli ${ }^{52}$ masallarında bu tipe rastlanmaktadır. Gagavuz Türk halk masallarında incelenen masallarda bu tiple karşılaşılmamıştır.

2.2.3.6. Üvey anne: Üvey anne, incelenen masalların tümünde kötülük yapan bir karakterdedir. Hatta Kıbrıs Türk halk masallarından Üvey Ana masalında kendi çocuklarına çok iyi bakan anne, üvey çocuklarını istemez ve kocasından kendi çocuklarını alıp ormana bırakmasını ister: "Benimle iyi geçinmek istersen, çocuklarını yarın götürüp ormana bırakacaksın." ${ }^{53}$ Kıbrıs Türk halk masallarından Merdane masalında da üvey annesi Merdane adlı kızı kıskanır ve kendisinde daha güzel olduğu için onu öldürmeyi planlar. ${ }^{54}$ Gagavuz Türk halk masallarında da üvey anne tipi belirgin bir karakter olarak bulunmaktadır. Örneğin; Üvey Anne ile Kızı,

\footnotetext{
${ }^{50}$ Uçkun, a.g.e., s. 601.

${ }^{51}$ Yorgancioğlu, a.g.e., s. 103-104.

${ }^{52}$ Yorganc1oğlu, a.g.e., s. 78-82, 89-92.

${ }^{53}$ Yorgancioğlu, a.g.e., s. 67.

${ }^{54}$ Yorganc1oğlu, a.g.e., s. 8-10.
} 


\section{KIBRIS VE GAGAVUZ TÜRK MASALLARINDAKİ KADIN KAHRAMANLAR VE SOSYO-KÜLTÜREL ROLLERI}

Kim Taa Gözäl, Öküze Dönüşen Çocuk ${ }^{55}$ masallarında kötü karakter olarak karşımıza çıkmaktadır.

\subsubsection{Masallarda yer alan kadınların Kıbrıs ve Gagavuz Türk kültürüne ait yönleri}

2.2.4.1. Düğün: Kıbrıs ve Gagavuz Türk kültüründe geçmişten günümüze devam eden bir gelenek olan düğün geleneği masallarda sikça geçmektedir. Kıbrıs Türk kültüründe düğün dernek kurup kırk gün kırk gece düğün yapmak bu kültürün çok önemli bir parçasıdır ve geçmişten günümüze devam edip gelen; kına, çeyiz, ziyafet gibi bazı geleneklerin devamlılığını da sağlayan önemli bir uygulamadır. ${ }^{56}$ İncelenen Kıbrıs Türk halk masallarında da kırk gün kırk gece düğün yapılmakta ve ziyafet verilmektedir. Kıbrıs'ta 1970'li yıllara kadar ziyafetle düğünler süregelmiştir. Günümüzde düğünler sadece birkaç saatte tamamlanan bir hal almıştır. Ancak kadının isteğine bağlı olarak dügünden 2-3 gece önce kına gecesi yapılabilmektedir.

Gagavuz Türk halk kültüründe de düğünün önemli bir yeri vardır. "Gagavuz Türklerinde dügünün evreleri genel olarak şu şekildedir: dügün öncesi, söz, nişan, yüzüm haftası, düğün ve gerdek (kırmızı rakı). Düğün öncesi evre, söz ve nişan geleneklerini içermektedir." ${ }^{57}$ Gagavuz Türk halk masallarında da düğün geleneğine rastlanmaktadır. Örneğin; Üvey Anne ile Kızı masalında ${ }^{58}$ annesi olmayan kıza babası tarafından büyük bir düğün yapılır ve kız evlendirilir. Öküze Dönüşen Çocuk masalında ${ }^{59}$ da padişahın oğlu kızı alır, büyük bir düğün yaparak evlenir.

2.2.4.2. Gergef (Kuzey Kıbrıs) yapağı (Gagavuz) ve kenevir işleme (Gagavuz): Genç Kız ile Güvercin ${ }^{60}$ ve Güvercin Şehzade ${ }^{61}$ masallarında gergef işleme yer almaktadır. Gergef işleme Kıbrıs Türk kadınları arasında yaygın olan bir el işi sanatıdır. Daire şeklinde içi içe geçmeli iki kasnağa kumaşın gerilip nakış işlenmesiyle yapılmaktadır.

\footnotetext{
${ }^{55}$ Uçkun, a.g.e., s.424,530-531.

${ }^{56}$ Mahmut İslamoğlu, Klbrıs Türk Folkloru. Ürün Yayınları, Ankara 2004, s. 25-55.

${ }^{57}$ Perçemli, a.g.e., s. 67.

${ }^{58}$ Uçkun, a.g.e., s. 424.

${ }^{59}$ Uçkun, a.g.e., s. 531.

${ }^{60}$ Yorgancioğlu, a.g.e., s. 137.

${ }^{61}$ Yorganc1oğlu, a.g.e., s. 152-153.
} 
Güvercin Şehzade masalında annesi kızına gergef işlemeyi öğretir ve bu sanat, usta-çırak ilişkisi içinde sürdürülür.

Gagavuz masallarında gergef işleme kültürü bulunmazken yapağ1 işleme geleneği bulunur. Bilindiği gibi "Koyundan kırkılmış kirli yüne 'yapağı' adı verilmektedir. Geniş anlamda ise yapağı, kırkım esnasında hayvanların üzerinden gömlek halinde çıkarılan ve bükülüp iplik yapılabilen tüm k1llar anlamına gelmektedir." ${ }^{2}$ Yapağ 1 işleme genel anlamda Anadolu'da (ve Türklerde) geçmişten günümüze devam edip gelen bir gelenektir. ${ }^{63} \mathrm{Bu}$ geleneğin Gagavuz Türklerinde de olduğu incelenen masallardan anlaşılmaktadır. Örneğin Kim Taa Gözäl masalında Güzel adlı kız ve arkadaşlarının yapağı işlediği görülmektedir.

Gagavuz Türk halk masallarında karşılaşılan diğer bir gelenek de kenevir işlemedir. Kenevirin saplarından iplik, dokuma ve kumaş yapıldığı bilinen kenevir Gagavuz Türk halk masallarından Hoburdan Kurtulan Akıllı Kız masalında da geçmektedir. Bu masal kenevirin ekilmesi, yetiştirilmesi ve işlenmesiyle ilgilidir ve masalda üç kız kardeşin kenevir işlediği görülür. ${ }^{64}$

2.2.4.3. Çeyiz: Çeyiz düzme geleneği de Kıbrıs Türk masallarında geçen bir diğer kültürel öğedir. Hem Güvercin Şehzade ${ }^{65}$ hem de Fislikanc1 Güzeli ${ }^{66}$ masalında çeyiz geçmektedir. Çeyiz, kızın evlenmeden önce evine götüreceği eşyaları ve çeşitli el işlerini içermektedir. ${ }^{67}$

Gagavuz Türklerinde de çeyiz geleneğinin olduğu bilinmektedir. ${ }^{68}$ Ancak incelenen masallarda çeyizle ilgili bir unsura rastlanmamıştır.

2.2.4.4. Ziyafet: Türk destanlarında ve halk hikâyelerinin çoğunda geçen ziyafet verme, toy düzenleme geleneği Kıbrıs Türk masalarında da

\footnotetext{
${ }^{62}$ Hacer Tüfekçi ve Mustafa Olfaz, "Yapağının Alternatif Kullanım Alanları”, Bahri Dağdaş Hayvancilık Araştırma Dergisi, Cilt 1, Say1 1, 2014, s. 19.

63 Tuncer Baykara, Türk Kültür Tarihine Bakışlar, Atatürk Kültür Merkezi Başkanlığı, Ankara 2001, s. 118.

${ }^{64}$ Uçkun, a.g.e., s. 513.

${ }^{65}$ Yorgancioğlu, a.g.e., s. 152-153.

${ }^{66}$ Yorganc1oğlu, a.g.e., s. 207-208.

${ }^{67}$ Mahmut İslamoğlu, Klbrıs Türk Folkloru, Ürün Yayınları, Ankara 2004, s. 38; Mahmut İslamoğlu, Kıbrıs Türk Kültür ve Sanatı. Yakın Doğu Üniversitesi Yayınları, Lefkoşa 1994, s. 52.

${ }^{68}$ Perçemli a.g.e., s. 67.
} 


\section{KIBRIS VE GAGAVUZ TÜRK MASALLARINDAKİ KADIN KAHRAMANLAR VE SOSYO-KÜLTÜREL ROLLERI}

yer almaktadır. İncelenen masallarda ziyafet ve yeme-içme düğünlerin sonunda yapılmaktadır. Sadece Sihirli Tencere ${ }^{69}$ masalında ihtiyar, bütün ahaliye varlıklı olduğu için ziyafet vermektedir.

İncelenen Gagavuz Türk halk masallarında ziyafetle ilgili bir bulguya rastlanmamış ancak Üvey Anne ile $\mathrm{K}_{1 z}{ }^{70}$ masalında yapılan büyük bir düğünden bahsedilir.

2.2.4.5. Mutfak kültürü: Kıbrıs Türk masalarında mutfak kültürü ile ilgili bazı yiyecek isimleri geçmektedir. Örneğin; Sihirli Tencere ${ }^{71}$ masalında kadın, sihirli bir tencereden, ona püryan ve imambayıldı yemeklerini pişirmesini ister ve yemek pişer. Bu yemekler geleneksel Kıbrıs Türk mutfağının özel yemeklerindendir. Diğer Kıbrıs Türk masalı olan Dokumacı $\mathrm{K}^{72}$ masalında da kadın oğlu için peksimet ve çörek yaptırır. Bunlar da Kıbrıs Türk mutfă̆ında yeri olan yiyeceklerdendir. İlahi Damın Aksın da Kazanın Altına Saklanasın ${ }^{73}$ masalında ise geleneksel nor ve hellim peyniri yapılmaktadır. Bu masalda kocakarı bir çobandır ve sağdığı sütlerden hellim ve nor yapmaktadır. Ör ve hellim Kıbrıs Türk kadınlarının evlerinde de yaptıkları geleneksel peynirlerdendir.

Gagavuz Türk halk masalarına bakıldığında burada da çeşitli yiyecek isimlerinin geçtiği görülmektedir. Örneğin; Trakalı Öküz masalında k11rma (lahana), kaurma (kavurma), süüş tauk (söğüş tavuk), biyaz ekmek (beyaz ekmek), biyaz şarap (beyaz şarap) vb. yiyecek içecek adları geçmektedir. ${ }^{74}$ Kadın bu masalda kızına yiyip içmesi için tavuk, ekmek ve şarap hazırlar. Özellikle şarabın burada yer alması yaşanan topraklarda üzüm yetiştiriciliği ve şarap yapımının yaygın olması ve Hristiyanlık diniyle ilgilidir.

2.2.4.6. Din ve inanç: Kıbrıs Türk masallarında yer alan kadınların İslam dinine inanan kadınlar olduğu görülmektedir. Dinî inanç, kültürün en önemli yapı taşlarından biridir. Hamur Kız masalında kadın, Allah'a dua eder ve duası sonunda bir kız çocuğu olur. ${ }^{75}$ Sabreden Derviş, Muradına

\footnotetext{
${ }^{69}$ Yorgancioğlu, a.g.e., s. 113.

${ }^{70}$ Uçkun, a.g.e., s. 424.

${ }^{71}$ Yorganc1oğlu, a.g.e., s. 113, 115.

${ }^{72}$ Yorganc1oğlu, a.g.e., s. 78-82.

${ }^{73}$ Yorgancioğlu, a.g.e., s. 56-57.

${ }^{74}$ Uçkun, a.g.e., s. 416-417.

${ }^{75}$ Yorgancioğlu, a.g.e., s. 103.
} 
Ermiş $^{76}$ masalında ise kız yemeni bağlayarak 39 gün Kur'an okuyup dua etmektedir. Allah inancına bağlı olarak da çeşitli söz ve deyimler de masallarda yer almaktadır: Allah iyiliğini versin, Allah talihini açık etsin, Bu kız Allah'ın bize nimetidir, Allah hayıra getirsin, Allah istedikten sonra her şey olur, bu kızı Allah'ın emrine istesin, Allah'ım sana çok şükür, Allah'a hamdolsun, Allah'ına şükretmiş, Allah'tan bulsun, Allah senden razı olsun, Allah yolunu açı etsin vs. ${ }^{77}$

Gagavuz Türklerinin Hristiyan olduğu bilinmektedir. Gagavuzlar bir yandan Hristiyanlık kültürlerini bir yandan da Türk-Şaman geleneklerini sürdürmektedirler. İki Moçuga masalında kadın, vaftiz edilmiş bir adamla evlenmektedir. ${ }^{78}$ Papaz ile Kızı ${ }^{79}$ masalında da kızın babası bir papazdır.

2.2.4.7. Nazar-Göz tutması: Kıbrıs Türk halk masallarından Hamur $\mathrm{K}_{1}{ }^{80}$ masalında hamurdan bir kız bebek sahibi olmaya çalışan anne, çocuğuna göz (nazar) değmemesi için onu kimselere göstermez. Göz değmesi ve nazar konusu Kıbrıs Türk inanç sisteminde şu an da var olan bir inançtır. Bundan korunmak için de Kıbrıs Türk kadınları dualar eder, İslami ayetler okur ve eski Şaman inançlarına/uygulamalarına dayalı olarak zeytin dalı yakıp tütsülenir. İncelenen Gagavuz halk masallarında nazar değmesi inancına rastlanmamıştır.

\section{Sonuç}

Kıbrıs ve Gagavuz Türk halk masalları sosyal, kültürel, psikolojik ve eğitimsel birçok özelliği içinde barındırmaktadır. Masaldaki aile ve toplum yapıs1; anlatıların sosyal yönünü, yerel-folklorik unsurlar; kültürel yanını, kahramanların tavır ve düşünceleri psikolojik yanını ve masalın anlatım bağlamı onun eğitsel yanını yansıtmaktadır. Bu yönleriyle sözlü gelenekte oluşup gelişen masallar oldukça önemli halk anlatılarıdır.

Masalların dikkat çekici yönlerinden birisi de anlatılarda rol alan kahramanların çeşitliliği ve farklılığıdır. Çünkü masallarda yer alan kahramanlar gerçek kahramanlar olabileceği gibi olağanüstü veya hayali

\footnotetext{
${ }^{76}$ Yorgancioğlu, a.g.e., s. 85.

77 Yorganc1oğlu, a.g.e., s. 152, 9, 103, 104, 67, 148, 79.

${ }^{78}$ Uçkun, a.g.e., s. 545.

${ }^{79}$ Uçkun, a.g.e., s. 565.

${ }^{80}$ Yorganc1oğlu, a.g.e., s. 103-104.
} 


\section{KIBRIS VE GAGAVUZ TÜRK MASALLARINDAKİ KADIN KAHRAMANLAR VE SOSYO-KÜLTÜREL ROLLERI}

kahramanlar da olabilmektedir. İncelenen metinlerden çıkan sonuca göre masal tiplerinin en fazla kişilik özellikleriyle masallarda yer aldığı görülmüştür (Kuzey Kıbrıs: \%240 - Gagavuz: \%190). Bu da toplumda dış görünüş ve statüden ziyade kişiliğe önem verildiği sonucunu doğurmaktadır. Bunun yanında statünün de toplumda dikkat edilen diğer bir unsur olduğu çıkan sonuçlardan anlaşılmaktadır (Kuzey Kıbrıs: \%105 - Gagavuz: 45).

Kadın tiplerin her iki ülkenin masallardaki işlevlerine ve rollerine bakıldığında ise birç̧ok kadının masalların olay örgüsünü doğrudan etkileyen rollerde konumlandırıldığı görülmektedir. Örneğin; üvey annenin olduğu bir masalda ana konu üvey anne ve onun davranışları üzerinde şekillendirilmektedir. Yine kıskanç kaynana (Kuzey Kıbrıs) veya kız kardeşlerin rol aldığ 1 bir masalda ana olay ve sürükleyici nokta, kıskanç kaynananın gelinine ve kıskanç ablaların kız kardeşlerine karşı olan tavırları ve hareketleridir. Yan karakterde olan kadınlar da masallarda etkili bir rol oynamaktadır. Bu yönleriyle kadının masallarda önemli işlevleri ve yönleri olduğu söylenebilir.

Kıbrıs ve Gagavuz Türk halk masallarında (her iki durumda da: eş, anne) kadının rollerini genelde iyi bir şekilde üstlendiği, geleneksel Kıbrıs ve Gagavuz Türk aile yapısında kendinden beklenenleri yerine getirdiği görülmektedir. İncelenen Kıbrıs Türk halk masallarının çoğunda kadın evinin temizliğini yapan, yemek pişiren, çocuklarını en iyi şekilde yetiştirmeye çalışan, eşi öldüğ̈̈ zaman başka bir adamla evlenmeyen, dul olmasına rağmen çocuklarını en iyi şekilde yetiştirmeye çalışan bir anne ve iyi bir eş tipiyle karşılaşılmaktadır. Tabi bunun yanında az da olsa kötü eşler veya anneler de bulunmaktadır. Örneğin; Cadaloz masalında çocuklarına çok sinirlenen anne onları firında yakarak öldürmektedir. ${ }^{81}$

Gagavuz Türk halk masallarında da kadının çocuklarına ve kocasına bağlı, koruyucu bir tip çizdiği görülmektedir. Bunun yanında eşine sadık ve evini çekip çeviren bir kadın tipi masallarda karşımıza çıkmaktadır. Ancak gerçek hayatta karşılaşılan kötü anne ve eş tipleri bu masallarda da görülmektedir.

Her iki ülkenin masalları karşılaştıııldığında Kıbrıs Türk halk masallarında kadının oldukça önemli ve fazla kullanılan bir tip olduğu görülmektedir. Gagavuz masallarında da kadının belirgin bir yeri olmasına

${ }^{81}$ Yorganc1oğlu, a.g.e., s. 178. 


\section{BURAK GÖKBULUT - MUSTAFA YENİASIR}

karşın Kıbrıs Türk halk masallarındaki kadar önemli bir yeri olmadığı görülür. Sosyolojik olarak genel toplum yapısına da bakıldığında Kıbrıs Türk toplumu içerisinde kadının oldukça önemli bir yerinin olduğu rahatça görülebilir.

Her iki toplumun masallarında olumsuz özellikler taşıyan ve kötü roller atfedilen kadınların da olduğu yadsınamaz bir gerçektir. Ancak genele bakıldığında toplumda olumlu bir kadın algısıyla karşılaşılmaktadır.

\section{KAYNAKÇA}

AKGÜL, Semra, "Kadın ve Aile Hayatı Konuları Bakımından Türkiye Türkçesi ve Gagavuz Türkçesi Atasözleri”, Türkiyat Mecmuası, Cilt 27, Sayı 2, 2017, s. 1-16.

BAYKARA, Tuncer, Türk Kültür Tarihine Baklşlar, Atatürk Kültür Merkezi Başkanlığı, Ankara 2001.

DAS, Ritamani, "Psychoanalytical Study of Folktale", IOSR Journal of Humanities and Social Science, Cilt 19, Sayı 10, 2014, s. 13-18.

EKİCI, Metin, "Anadolu Sahası Köroğlu Anlatmalarında Kadın Tipler", Millî Folklor, Cilt 6, Say1 44, 1999, s. 10-17.

, "Dede Korkut Kitabında Kadın Tipleri", Ed. Birgül, A. K., Canpolat, A. Ş. Uluslararası Dede Korkut Bilgi Şöleni Bildiri Kitabı, Atatürk Kültür Merkezi Başkanlığı Yay., Ankara 2000, s. 123-138.

ERGIN, Muharrem, Dede Korkut Kitabı, Boğaziçi Yayınları, İstanbul 2017.

İNAN, Abdülkadir, "Türk Mitolojisinde ve Halk Edebiyatında Kadın", Makaleler ve İncelemeler, Türk Tarih Kurumu Yayınları, Ankara 1998, s. 274-280.

İSLAMOĞLU, Mahmut, Kıbrıs Türk Folkloru. Ürün Yayınları, Ankara 2004. 


\section{KIBRIS VE GAGAVUZ TÜRK MASALLARINDAKİ KADIN KAHRAMANLAR VE SOSYO-KÜLTÜREL ROLLERİ}

Lefkoşa 1994.

Kıbrıs Türk Kültür ve Sanatı, Yakın Doğu Üniversitesi Yayınları,

MANDALOĞLU, Mehmet, "İslamiyet’ten Önce Türklerde Aile Hukuku", Selçuk Türkiyat Araştırmaları Dergisi, Cilt 1, Sayı 33, 2013, s. 133-159.

PERÇEMLİ, Valentina, Gagauz Türklerinde Doğum, Evlenme ve Ölüm Âdetleri, Ege Üniversitesi Sosyal Bilimler Enstitüsü, Yayımlanmamış Doktora Tezi, Danışman: Prof. Dr. Kemal Yüce, İzmir 2011.

SADIÇ, Aysun, Masallarda Kadın-Güneydoğu Anadolu ve Doğu Karadeniz Masal Örnekleri, Gaziantep Üniversitesi Sosyal Bilimler Enstitüsü, Yayımlanmamış Yüksek Lisans Tezi, Danışman: Yrd. Doç. Dr. Behiye Köksel, Gaziantep 2008.

TELLİĞLU, İbrahim, "İslam Öncesi Türk Toplumunda Kadının Konumu Üzerine", Atatürk Üniversitesi Türkiyat Araştırmalarl Enstitüsü Dergisi, Say1 55, 2016, s. 209-224.

TÜFEKÇİ, Hacer - OLFAZ, Mustafa, "Yapağının Alternatif Kullanım Alanları", Bahri Dağdaş Hayvancılık Araştırma Dergisi, Cilt 1, Say1 1, 2014, s. 18-28.

TÜRKMEN, Fikret, Âşı Garip Hikâyesi Üzerinde Mukayeseli Bir Araştırma, Akçağ Yayınları, Ankara 1995.

UÇKUN, Rabia, Gagauz Masallarının Tip ve Motif Yapısı Bakımından Incelenmesi, Ege Üniversitesi Sosyal Bilimler Enstitüsü, Yayımlanmamış Doktora Tezi, Danışman: Prof. Dr. Fikret Türkmen, İzmir 2003.

YILDIRIM, Ali - ŞİMŞEK, Hasan, Sosyal Bilimlerde Nitel Araştırma Yöntemleri, Seçkin Yayıncılık, Ankara 2006.

YILMAZ, Ayfer, “Türk Kültüründe Kadın”, Millî Folklor, Cilt 16, Sayı 61, 2004, s. 111-123.

YORGANCIOĞLU, Oğuz, Kıbrıs Türk Folklorundan Derlemeler-Masallar II, Canbulat Yayınevi, Mağusa 2006. 